\title{
Haggai Ram
}

\section{TO BANISH THE "LEVANTINE DUNGHILL" FROM WITHIN: TOWARD A CULTURAL UNDERSTANDING OF ISRAELI ANTI-IRAN PHOBIAS}

This article inquires into Israel's understandings of its conflict with Iran by relocating analysis from the realm of political-strategic issues, with which previous scholarship on Israel and Iran has been preoccupied, to the realm of culture. The article draws on works that read metropolitan and colonial cultures together, or contrapuntally. By studying one history (Iranian) as at once the condition and the effect of the other history (Israeli), I show that Israelis fashioned and comprehended the post 1979 Iranian polity on the basis of what they believed to be the (dis)ordering of their society at home. In this way, Israeli perceptions of Iranians as alien and threatening have turned into a defensive protection of the home front. Anti-Iran phobias in the Israeli public sphere reveal not only justified strategic concerns, but also fears of "Oriental" (Mizrahi) and ultrareligious, Iran-like "demons" operating within the Israeli polity. The Israeli sense of danger emanating from Iran is related to the very process of demarcating and safeguarding the Jewish state's Western character. 